OPEN ACCESS

Edited by:

Paul H. A. Quax

Leiden University, Netherlands

Reviewed by:

Taisiya Bezhaeva,

Leiden University Medical

Center, Netherlands

Margreet R. De Vries,

Leiden University Medical

Center, Netherlands

*Correspondence:

Alan Dardik

alan.dardik@yale.edu

orcid.org/0000-0001-5022-7367

Specialty section:

This article was submitted to

Atherosclerosis and Vascular

Medicine,

a section of the journal

Frontiers in Cardiovascular Medicine

Received: 26 May 2021

Accepted: 24 June 2021

Published: 21 July 2021

Citation:

Chan SM, Weininger G, Langford J, Jane-Wit D and Dardik A (2021) Sex

Differences in Inflammation During Venous Remodeling of Arteriovenous

Fistulae.

Front. Cardiovasc. Med. 8:715114.

doi: 10.3389/fcvm.2021.715114

\section{Sex Differences in Inflammation During Venous Remodeling of Arteriovenous Fistulae}

\author{
Shin Mei Chan ${ }^{1}$, Gabe Weininger ${ }^{1}$, John Langford ${ }^{1,2}$, Daniel Jane-Wit ${ }^{1,3,4}$ and \\ Alan Dardik ${ }^{1,2,5 *}$ \\ ${ }^{1}$ Vascular Biology and Therapeutics Program, Yale School of Medicine, New Haven, CT, United States, ${ }^{2}$ Department of \\ Surgery, Yale School of Medicine, New Haven, CT, United States, ${ }^{3}$ Division of Cardiovascular Medicine, Department of \\ Internal Medicine, Yale School of Medicine, New Haven, CT, United States, ${ }^{4}$ Department of Immunobiology, Yale School of \\ Medicine, New Haven, CT, United States, ${ }^{5}$ Department of Surgery, Veterans Affairs (VA) Connecticut Healthcare System, \\ West Haven, CT, United States
}

Vascular disorders frequently have differing clinical presentations among women and men. Sex differences exist in vascular access for hemodialysis; women have reduced rates of arteriovenous fistula (AVF) maturation as well as fistula utilization compared with men. Inflammation is increasingly implicated in both clinical studies and animal models as a potent mechanism driving AVF maturation, especially in vessel dilation and wall thickening, that allows venous remodeling to the fistula environment to support hemodialysis. Sex differences have long been recognized in arterial remodeling and diseases, with men having increased cardiovascular events compared with pre-menopausal women. Many of these arterial diseases are driven by inflammation that is similar to the inflammation during AVF maturation. Improved understanding of sex differences in inflammation during vascular remodeling may suggest sex-specific vascular therapies to improve AVF success.

Keywords: vascular inflammation, arteriovenous fistulae, sex differences, estrogens, androgens sex differences in venous inflammation

\section{INTRODUCTION}

Although sex differences exist in the epidemiology and clinical presentation of vascular pathologies, patient sex rarely plays a role in guiding medical or surgical management or specific therapeutic treatments. Sex differences in arterial pathologies have frequently been observed in clinical practice, with women presenting with symptoms of coronary artery disease at later ages and with different presentations compared with men; the later age of presentation is frequently after menopause when estrogen levels decrease (1). One explanation is that female hormones provide an anti-inflammatory effect; both estrogen and estrogen receptors exert cardioprotective effects by attenuating inflammatory cytokines, including interleukin-8 (IL-8) and monocyte chemoattractant protein-1 (MCP-1) as well as recruitment of leukocytes (2).

A global rise in end-stage renal disease has resulted in increased placement of autogenous arteriovenous fistulae (AVF), particularly in light of the "Fistula First Breakthrough Initiative" published by the National Kidney Foundation in 2003 (3). This campaign pushed to attain a target of $40 \%$ of autologous AVF in the United States by 2006, and then $66 \%$ by 2009 (4). Despite these efforts to increase AVF use, up to $60 \%$ of AVF fail to mature by 5 months contributing to significant patient burden and healthcare cost $(3,5)$. There are several predictors of successful AVF adaptation 
to the fistula environment and use as a successful conduit for hemodialysis, although none are perfect (6). Vein diameter is the most predictive factor in many studies, with larger preoperative vein diameters correlating with higher rates of maturation $(7,8)$. Other factors, such as diabetes, congestive heart failure, concomitant peripheral arterial disease, and older age may also play a role, as these are negatively correlated with successful AVF creation $(5,8)$.

Female sex also predicts poor fistula outcomes. Women are less likely to undergo fistula surgery, and when placed, AVF created in women take longer to mature and have higher rates of non-maturation compared with men $(3,9)$. In elderly patients, at 6 months post-surgery, women are less likely to be successfully dialyzed via their fistula, and at 1 year post-surgery, fistulae are more likely to be completely abandoned in women (10). In women, the time to fistula maturation may also be prolonged compared with men, and women also require more frequent salvage procedures $(9,11)$. Several hypotheses have been proposed to explain the sex discrepancy in rates of AVF maturation, including smaller mean vessel diameters, greater vascular reactivity following vascular injury, and decreased capacity for venous dilation in women (9). Given the worse clinical outcomes of AVF in women and growing evidence of sex differences in both venous and arterial inflammation, we review the evidence for sex differences in inflammation that occurs during venous remodeling that may contribute to discrepancies in AVF maturation.

\section{VENOUS REMODELING}

Surgical creation of an AVF results in remodeling of the venous outflow; successful hemodialysis depends on venous remodeling, that is venous dilation and wall thickening, to withstand the high flows required for efficient hemodialysis sessions and puncture with large bore needles 3 times a week (12). Venous remodeling has been studied frequently in the context of vein graft adaption; inflammation regulates vein graft adaptation and sex differences in inflammation may be a mechanism of the reduced vein graft patency among women $(13,14)$. Analysis of the Project of Ex Vivo Vein Graft Engineering via Transfection III (PREVENT III) clinical trial showed that both sex and race predict vein

\footnotetext{
Abbreviations: AAA, Abdominal aortic aneurysm; AMPK, $5^{\prime}$ adenosine monophosphate-activated protein kinase; AP-1, Activator protein-1; AVF, Arteriovenous fistula; BMP, Bone morphogenic protein; CC, Cysteinecysteine; CD, Cluster of differentiation; CINC, Cytokine-induced neutrophil chemoattractant; CX3CR1, Cysteine-X3-cysteine motif chemokine receptor 1; ECM, Extracellular matrix; eNOS, Endothelial nitric oxide synthase; Eph-B4, Ephrin type B receptor 4; ER- $\alpha$, Estrogen receptor- $\alpha$; ICAM-1, Intercellular adhesion molecule 1; IL, Interleukin; JAK, Janus kinase; JNK, c-Jun N-terminal kinase; KLF2, Kruppel-like factor 2; LPS, Lipopolysaccharide; M-CSF, Macrophage colony-stimulating factor; MCP-1, Monocyte chemoattractant protein-1; MMP,

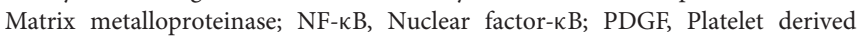
growth factor; PPAR, Peroxisome proliferator-activated receptor; SOC3, Suppressor of cytokine signaling; STAT, Signal transducer and activator of transcription; TAA, Thoracic abdominal aneurysm; TAK1, TGF- $\beta$ activated kinase-1; TGF- $\beta$, Transforming growth factor- $\beta$; TIMP, Tissue inhibitor of metalloproteinases; TNF- $\alpha$, Tumor necrosis factor- $\alpha$; VCAM-1, Vascular cell adhesion molecule-1.
}

graft patency; black women are more likely to experience loss of vein graft patency and major amputation following bypass surgery (15). However, although AVF maturation and vein graft adaptation both reflect venous remodeling, these processes differ as they take place in different environments and result in different structures (12).

Animal models have shown that venous remodeling during AVF maturation is characterized by increased expression of the venous determinant Ephrin type $\mathrm{B}$ receptor 4 (Eph-B4) and the arterial determinant Ephrin-B2, as well as temporal regulation of expression of multiple components of the extracellular matrix (ECM), allowing venous adaptation to the fistula environment without loss of structural integrity $(16,17)$. Members of the ephrin family mediate cell-cell signaling to promote tissue development and remodeling. In embryogenic tissue, ephrins and their Eph receptors regulate angiogenesis and lymphangiogenesis; in adult endothelial tissues, expression of ephrins are associated with arterial and venous remodeling (16, 18). Expression of both Eph-B4 and Ephrin-B2 show plasticity in adults after surgical manipulation; in vein grafts placed in an arterial environment, Eph-B4 expression is decreased, but expression of arterial markers is not increased (19). However, in AVF, expression of both venous markers such as Eph-B4 and arterial markers such as Ephrin-B2 are increased, resulting in venous remodeling via an Akt1-mediated mechanism (16). During vascular remodeling, ephrins are upregulated by tumor necrosis factor alpha (TNF- $\alpha$ ) and regulate nuclear factor $-\kappa B$ $(\mathrm{NF}-\kappa \mathrm{B})$, a potential pathway regulating inflammatory processes in endothelial cells (20). In addition Ephrin-B2 promotes leukocyte extravasation and infiltration necessary for vascular remodeling associated with arteriosclerosis (21).

Sex differences involving Eph-B4 and Ephrin-B2 within the vascular system have not been described. However, sex differences have been described in downstream targets. One target of Eph-B4 is Akt, which phosphorylates endothelial NO synthase (eNOS), a critical mediator of venous dilation (22). Phosphorylated eNOS is increased in vein grafts, and absence of eNOS prevents thickening and remodeling of the venous wall (22). In an elegant analysis of a murine AVF model, eNOS mediates dilation of the remodeling vein exposed to the fistula environment; overexpression of eNOS was associated with larger diameter and less neointimal hyperplasia, and eNOS knockout was associated with small diameter and increased neointimal hyperplasia. eNOS overexpression was also associated with smoother blood flow streamlines, less shear stress at the vessel wall, luminal fluid vorticity, and radial wall thinning. These data suggest that eNOS increases NO release from endothelial cells to stimulate smooth muscle cell relaxation (23).

Interestingly, in ovariectomized mice, estrogen induces eNOS to produce and release NO from endothelial cells via the Akt pathway, leading to subsequent arterial dilation (24). In human endothelial cells, there is greater eNOS expression and activation in female-derived cells (25). After menopause there are reduced circulating estrogens, with subsequent reduced arterial NO, that likely contributes to the increased risk for cardiovascular events observed in post-menopausal women compared with pre-menopausal women (26-28). Thus, while sex differences in 
Eph-B4 and Ephrin-B2 expression have not yet been reported, components of the Eph signal transduction pathway shows sex differences, suggesting that this family of ligands and their receptors may play a large role in the observed differences in venous remodeling.

Transforming growth factor (TGF)- $\beta$ and TGF- $\beta$ activated kinase-1 (TAK1) are also important mediators of venous remodeling that promotes wall thickening and dilation by regulating ECM deposition, collagen, fibronectin, and lumen dilation necessary for AVF maturation $(29,30)$. In endothelial cells, TGF- $\beta$ can stimulate inflammation and fibrosis via expression of cell adhesion molecules such as intercellular adhesion molecule 1 (ICAM-1) and vascular cell adhesion molecule 1 (VCAM-1), matrix metalloproteinases such as MMP2 , and fibronectins (31). Increased expression of TGF- $\beta$ during early venous remodeling is likely required for initial maturation of fistulae, and may be a mechanism of compensation to hemodynamic changes, but sustained increased TGF- $\beta$ and platelet derived growth factor (PDGF) expression likely leads to neointimal hyperplasia that contributes to late AVF failure (32). Several TGF- $\beta$ polymorphisms alter TGF- $\beta$ expression and may determine late AVF patency rates in human patients (33). However, sex differences in the TGF- $\beta$ pathway and downstream effects on the ECM have not been adequately assessed during AVF maturation, despite strong evidence that sex hormones directly interact with the TGF- $\beta$ superfamily (34). It is possible that sex differences in upstream regulatory pathways, such as in toll-like receptors, may also exist (35).

Since remodeling of the vein during AVF maturation results in expression of both arterial and venous identities in the remodeled venous wall, understanding of sex differences in arterial remodeling may suggest mechanisms relevant to venous remodeling (Table 1). Arterial remodeling involves multiple inflammatory processes. Inflammation and vasoactive peptides promote vessel remodeling by promoting the migration of monocytes and macrophages into the vascular wall, mediated by cell adhesion proteins such as ICAM-1 and VCAM (44, 45). Increased shear stress also promotes vascular remodeling by upregulating TNF- $\alpha$ and NF- $\kappa$ B, as well as activating cellular adhesion molecules to recruit leukocytes (46). Sex differences present during arterial remodeling may be relevant to venous remodeling.

In arterial remodeling, estradiol administration inhibits monocyte migration in a MCP-1-dependent manner (47). In human endothelial cells treated with lipopolysaccharide (LPS) to induce VCAM-1 expression, estradiol decreases VCAM-1 expression to a greater extent, compared with dexamethasone, by inhibiting NF-kB, activator protein-1 (AP-1), and GATA (48). Estradiol can also influence ICAM-1 expression; treatment of endothelial cells with estradiol leads to a shift from the NF-kB pathway to the c-Jun N-terminal kinase (JNK)/AP-1 pathway (49). Estradiol treatment inhibits TNF- $\alpha$-dependent VCAM-1 and ICAM-1 expression, as well as inhibition of NF$\mathrm{kB}$ via activation of AMP-activated protein kinase (AMPK) and peroxisome proliferator-activated receptor (PPAR)- $\alpha$ (50). Conversely, administration of androgens to both female and male human endothelial cells shows increased TNF- $\alpha$ signaling and greater expression of inflammatory cytokines, and increased
VCAM-1 expression (51). Since sex differences are present in inflammation-driven arterial remodeling, it is likely that similar sex differences exist in venous remodeling.

\section{VENOUS DILATION}

After an AVF is created, early outward remodeling of the vein is driven by Poiseuille's law, whereby contact with the higher arterial pressure, flow and oxygen content leads to increased venous diameter; this increased diameter, and thus increased volume of the vessel, is necessary for the vein to accommodate increased magnitudes of shear stress and volume flow (12). Preoperative vein diameter is a main predictor of clinical AVF success; in a retrospective review, Lauvao et al. showed that vein diameter was the only independent predictor of fistula maturation (odds ratio $=0.15$ ) $(8)$. Of note, women frequently have smaller diameter vessels compared with men; in a mouse AVF model, outflow veins in male mice were larger than female mice immediately after surgery, and remained larger postoperatively $(8,37,52)$.

Outward remodeling is driven by immune and inflammatory processes, particularly CD4 + T cells (53). Rats devoid of mature $\mathrm{T}$ cells have decreased lumen sizes following AVF surgery and lower inflammatory cell counts at the fistula site; rescue with euthymic CD4+ T cells leads to increased blood flow through the fistula (54). Sex differences have yet to be assessed in the T cellmediated venous dilation observed during AVF maturation. However, estrogen can influence Th responses, promote Treg cell populations, and mediate IL-17 release (55). Notably, estrogens can dampen inflammatory responses by modulating Th1 responses to Th2 responses (56). In addition, men have higher Th1:Th2 cytokine ratios (57). Future work is necessary to identify sex-associated differences in T cell-mediated outward remodeling in AVF.

MMP may also play sex-dependent roles in inflammatory venous remodeling. MMP are a family of zinc-dependent endopeptidases that degrade collagen and elastin in the ECM and have been implicated in dilatory venous and arterial diseases, including chronic venous insufficiency and aneurysmal disease (58-60). MMP are secreted by various cell types, particularly inflammatory cells (i.e., lymphocytes, macrophages, neutrophils), endothelial cells, and vascular smooth muscle cells (58). In chronic venous disease, multiple MMP have been implicated (58). During AVF maturation, serum levels of MMP-2, MMP-9, and metalloproteinase tissue inhibitors (TIMP) are associated with successful creation of AVF; higher MMP2/TIMP-2 and MMP-9/TIMP-2 ratios were associated with better prognosis (61).

Notably, the relaxin family of hormones upregulates MMP2 and MMP-9 expression to contribute to vessel remodeling $(62,63)$, suggesting that relaxin-relaxin receptor signaling might be a significant contributor to the sex differences present during AVF maturation as relaxin and its downstream molecules differ between sexes (64-68). Knockout of the relaxin receptor resulted in decreased outward remodeling in a murine model of AVF failure, accompanied by increased elastin content, reduced elastase activity, increased $\mathrm{CD} 45+$ leukocytes, and increased MCP-1 expression (69). Chronic administration 
TABLE 1 | Observed sex differences in clinical studies and animal models.

\begin{tabular}{|c|c|c|c|c|c|}
\hline Indication & Model & Inflammatory marker & Men:Women & Women:Men & References \\
\hline \multirow[t]{2}{*}{ AVF } & Mice & KLF2, eNOS, VCAM-1 & $\begin{array}{l}\uparrow \text { in male mice following } \\
A V F \text { creation }\end{array}$ & & (36) \\
\hline & Mice & $\begin{array}{l}\text { TGF- } \beta 1, \text { TGF } \beta-R 1, \alpha \text {-smooth muscle } \\
\text { actin, fibroblast-specific protein- } 1 \text {, } \\
\text { CD } 68+\end{array}$ & & $\begin{array}{l}\uparrow \text { in female mice following } \\
\text { AVF creation }\end{array}$ & (37) \\
\hline \multirow[t]{10}{*}{ AAA } & Human & $\begin{array}{l}\text { Peripheral blood mononuclear cells } \\
\text { (Monocytes, B-cells, T cells) }\end{array}$ & $\begin{array}{l}\uparrow \text { in men with AAA } \\
\text { compared with men without } \\
\text { AAA (effect not seen in } \\
\text { women) }\end{array}$ & & (38) \\
\hline & Human & MMP-9 & & $\begin{array}{l}\uparrow, \text { compared with men with } \\
\text { AAA }\end{array}$ & (39) \\
\hline & Rat & Neutrophils & $\uparrow$ in elastase-perfused rat & & $(40)$ \\
\hline & & & & $\downarrow$ in elastase-perfused rat & $(41)$ \\
\hline & Rat & Macrophages & $\uparrow$ in elastase-perfused rat & & \\
\hline & & & & $\downarrow$ in elastase-perfused rats & $(41)$ \\
\hline & Rat & MMP-13 & $\uparrow$ in elastase-perfused rats & & $(40)$ \\
\hline & Rat & BMP, TNF ligands & & $\downarrow$ in elastase-perfused rats & $(41)$ \\
\hline & Rat & TGF- $\beta$ and VEGF & & $\downarrow$ in elastase-perfused rats & $(41)$ \\
\hline & Mice & $\begin{array}{l}\text { JNK1 and downstream proMMP9, } \\
\text { proMMP2, active MMP2 }\end{array}$ & $\uparrow$ in elastase-perfused mice & & $(42)$ \\
\hline Atherosclerosis & Human & $\begin{array}{l}\text { CD68+, CD3+, macrophage foam } \\
\text { cells }\end{array}$ & & $\uparrow$ in carotid plaque caps & $(43)$ \\
\hline
\end{tabular}

$\uparrow$, Increased and $\downarrow$, decreased.

of recombinant relaxin reduces arterial load by decreasing systemic vascular resistance, reduces pulsatile arterial load by increasing compliance, and increases cardiac output in female mice (65); interestingly, there were no sex differences, despite relaxin being considered specific to female physiology (64, 66). Elastins may also be involved in the sex differences of vessel remodeling, as estrogen may decrease MMP-9 production, thus decreasing elastin degradation (70). Elastin haplodeficient mice show increased outward remodeling, without increased intimal hyperplasia, resulting in larger diameter venous outflow tracts (71). Although the data showing elastin regulates venous remodeling is strong in animal models, human clinical trials with recombinant elastase did not show clear improvements in AVF outcomes $(72,73)$.

The inflammatory process of venous outward remodeling may be similar to remodeling that occurs during the formation of arterial aneurysms (Figure 1). Sex differences in arterial aneurysms have been extensively described. Both thoracic aortic aneurysms (TAA) and abdominal aortic aneurysm (AAA) occur less commonly in women than in men (74). Women, however, have worse prognosis; in women, AAA and TAA grow at faster rates, rupture at smaller diameters, and are associated with higher mortality (75-81). Aortic stiffness predicts TAA growth in women but not men, further suggesting a potential sex difference in the pathophysiology (81). In addition, women develop AAA at older ages than men (82), which has been suggested to be associated with menopausal status and decreasing estrogen levels (39).

Similar to venous remodeling, AAA are driven by $\mathrm{T}$ cellmediated inflammatory processes (Table 2); both $\mathrm{CD}^{+}$ and $\mathrm{CD}^{+}$T-cells are highly activated in the aortic wall, and perivascular $\mathrm{T}$ cell counts correlate with aneurysm progression (89). Th2 cytokines, particularly IL-1, IL-4, and IL-10, simultaneously activates MMP, which promotes the outward remodeling of the aneurysmal wall (90-92). Estradiol attenuates inflammatory cytokines and chemokines necessary for MMP-2 and MMP-9 release and monocyte infiltration, which protect against AAA; this may be mediated through the JNK pathway $(42,70)$. Similarly, following aortic elastase perfusion in male rats there are increased numbers of infiltrating macrophages compared with female rats, and treatment with estrogen in male rats leads to smaller aneurysms accompanied by decreased macrophage infiltration $(41,70)$. Human aortic smooth muscle tissue incubated in testosterone showed increased MMP-3 expression, whereas incubation with estrogen and progesterone reduced collagen deposition and increased elastin deposition (83). In rats, MMP-13 expression is increased in male rats perfused with elastase compared with female rats (40). In mice, increased estrogen receptor- $\alpha$ (ER- $\alpha)$ in female mice was inversely correlated with MMP activity and aneurysm formation (84). Estrogen administration decreases MMP-2 and-9 expression, adhesion molecule expression and macrophage stimulators such as ICAM-1, VCAM-2, E-selectin, MCP-1, and macrophage colony-stimulating factor (M-CSF) $(38,70,85)$. Since estrogen plays a protective mechanism in AAA formation via the inflammatory MMP pathway, further research is needed to understand the contribution of this mechanism to fistula maturation.

\section{VENOUS WALL THICKENING}

Vascular remodeling is composed of both changes in vessel diameter as well-changes in wall thickness. Excessive venous 


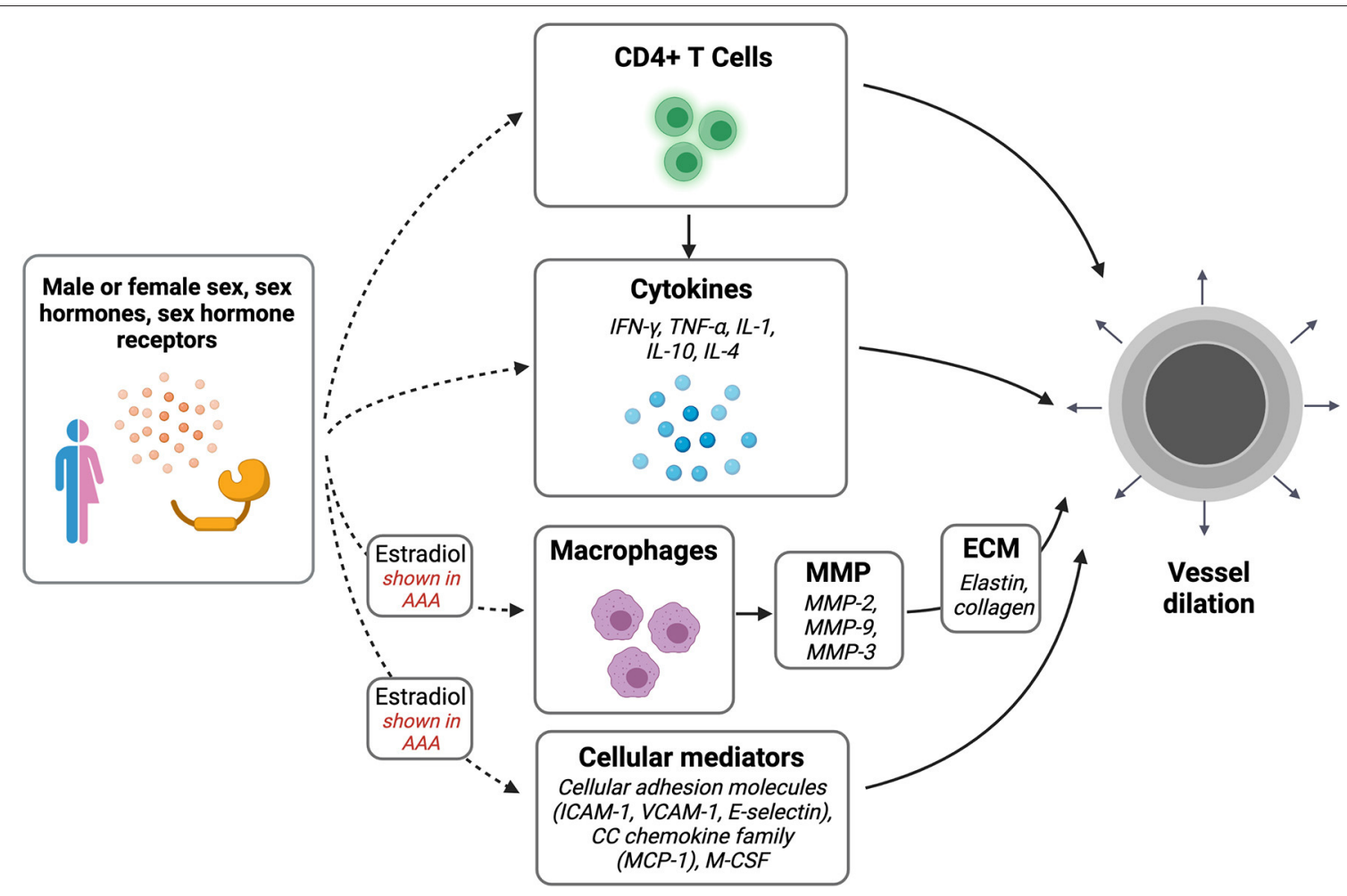

FIGURE 1 | Sex differences in vascular dilation. Potential pathways of interest in vessel wall dilation that may be affected by sex, sex hormones, and sex hormone receptors. Created with BioRender.com.

neointimal thickening leads to late AVF failure, observed more commonly in women than men (9). Venous neointimal thickening also depends on Eph function; in mouse models, decreased Eph-B4 signaling is associated with increased venous wall thickening $(16,93)$. Eph-B4 also regulates wall thickening in human veins, at least in vitro (94-96).

Interestingly, recent data using a mouse AVF model has shown that Kruppel-like factor 2 (KLF2), eNOS, and VCAM-1 increase in male but not female mice, despite being similar at baseline prior to AVF creation; in addition, female mice showed reduced laminar shear stress that was followed by reduced AVF patency at 42 days (36). Transcriptome RNA sequencing has also showed that inflammatory pathways are differentially upregulated in male mice following AVF creation; expression of proinflammatory cytokine IL-17 was less in females, but fibrotic markers TGF- $\beta 1$ and TGF- $\beta$ receptor 1 were increased, with correlation to negative vascular remodeling and increased medial fibrosis $(36,37)$. HIF- $1 \alpha$ and heme oxygenase- $1 / 2$ are also inflammatory mediators of neointimal hyperplasia that forms during AVF maturation and that may differ between sexes (97-99). Although partial HIF-1 $\alpha$ deficiency regulates differential changes in cardiac gene expression between female and male mice (100), and heme oxygenase expression differs in the setting of trauma and hemorrhage (101), sex differences in these mediators have not been studied in the setting of venous remodeling.

Macrophages and $\mathrm{T}$ cells contribute significantly to venous neointimal hyperplasia and may further contribute to sex differences observed during AVF maturation (53). Following angioplasty of fistulae, female mice had increased neointimal area-to-media ratio, accompanied by increased numbers of CD68+ cells, suggesting sex differences in macrophages during venous remodeling (102). M2-type macrophages are important for vascular wall thickening by secreting IL-10 that is necessary for wall thickening during AVF maturation (53, 103). Rapamycin, an immunosuppressant, decreases AVF wall thickness, ECM deposition, and smooth muscle cell proliferation via suppression of both M1-type and M2-type macrophages (104). The fractalkine receptor 1 (CX3CR1) reduces venous stenosis in AVF by decreasing proinflammatory signaling, including TNF- $\alpha$, IL-1 $\beta$, MCP- 1 , and NF-kB (105). In a murine AVF model, liposomal prednisolone inhibits venous inflammation and improves outward remodeling; inflammatory cytokine release from M1-type macrophages was reduced, suggesting conversion of macrophages into an anti-inflammatory profile (106). However, no significant effects on neointimal hyperplasia were observed, similar to the lack of efficacy observed in the human Liposomal Prednisolone to Improve Hemodialysis Fistula Maturation (LIPMAT) clinical trial (106, 107). These data suggest that the role of inflammatory signaling during AVF maturation is complex, and additional studies that separately examine the role of inflammation during early maturation and later patency are warranted.

In both atherosclerosis and arterial neointimal hyperplasia, macrophages have been implicated in sex differences (Figure 2) (108). Notably, men have more frequent atherosclerotic-related 
TABLE 2 | Differences in vascular inflammation due to sex hormones in clinical studies and animal models.

\begin{tabular}{|c|c|c|c|c|c|}
\hline Indication & Model & Inflammatory marker & Androgen-related & Estrogen-Related & References \\
\hline \multirow[t]{5}{*}{ AAA } & Human & MMP-3 & $\uparrow$ & & (83) \\
\hline & Mice & MMP-2, MMP-9 & & $\begin{array}{l}\downarrow \text { (inversely correlated with } \\
\text { estrogen receptor } \alpha \text { ) }\end{array}$ & (84) \\
\hline & & & & $\begin{array}{l}\text { Ovariectomy resulted in } \\
\text { higher levels of MMP-2 and } \\
\text { MMP-9 }\end{array}$ & (38) \\
\hline & Mice & $\begin{array}{l}\text { ICAM-1, VCAM-2, E-selectin, MCP-1, } \\
\text { M-CSF }\end{array}$ & & $\downarrow$ & (85) \\
\hline & Mice & $\begin{array}{l}\text { IL-1 } \alpha \text { mediated inflammatory } \\
\text { response (MCP-1, MMP-2, MMP-9), } \\
\text { TGF- } \beta\end{array}$ & $\begin{array}{l}\uparrow \text { (knock-out of AR leads to } \\
\downarrow)\end{array}$ & & (86) \\
\hline \multirow[t]{7}{*}{ Atherosclerosis } & Human & Monocyte migration & & $\begin{array}{l}\downarrow \text {, in a MCP-1 dependent } \\
\text { manner }\end{array}$ & $(47)$ \\
\hline & & & & $\begin{array}{l}\downarrow \text { via TNF- } \alpha, N F-k B \\
\text { inhibition }\end{array}$ & (50) \\
\hline & Human & ICAM-1 & No significant change & & (51) \\
\hline & & & & $\begin{array}{l}\downarrow \text { via TNF- } \alpha, N F-k B \\
\text { inhibition }\end{array}$ & (50) \\
\hline & & & & $\begin{array}{l}\text { Causes shift in pathway } \\
\text { (NF-kB JNK/AP-1) }\end{array}$ & (49) \\
\hline & Human & E-selectin & No significant change & & (51) \\
\hline & Rats & $\begin{array}{l}\text { Adhesion molecules (P-selectin, } \\
\text { VCAM-1, ICAM-1), monocyte } \\
\text { chemoattractant (CINC-2 } \beta \text {, MCP-1), } \\
\text { proinflammatory mediators (IL-1, IL-6) }\end{array}$ & & $\downarrow$ & (87) \\
\hline
\end{tabular}

$\uparrow$, Increased and $\downarrow$, decreased.

events and at younger ages compared with women, but cardiovascular diseases increase in women after menopause, suggesting significant sex hormone-dependent factors $(109,110)$. Sex differences are also present in the content of inflammatory cells in atherosclerotic lesions; for example, carotid plaque caps show more CD68+ and CD3+ inflammatory cells, including macrophage foam cells, in women compared with men (43). Macrophages express sex hormone receptors; higher levels of ER$\alpha$ in premenopausal women are associated with a lower incidence of atherosclerosis (108). In addition, estradiol can attenuate macrophage foam cell formation within atherosclerotic plaques, via JAK/STAT/SOC3 pathway (88). Interestingly, administration of androgens to human male-derived macrophages showed increased expression of inflammatory genes associated with atherosclerosis, but not in female-derived macrophages, further suggesting differential susceptibilities to atherosclerosis based on sex (111). Thus, similar to sex differences observed in arterial neointimal hyperplasia, macrophages may contribute to sexrelated differences in late AVF failure.

Vascular smooth muscle cells also play a dynamic role during AVF maturation. Differentiated, mature smooth muscle cells primarily contribute to medial wall thickening and dedifferentiated smooth muscle cells contribute to neointimal hyperplasia $(112,113)$. Sex differences in smooth muscle cell function have not been directly studied during AVF remodeling; however, it is reasonable that these differences exist, as studies in arterial neointimal hyperplasia have shown that smooth muscle cells function in a sex-dependent manner. In vein grafts implanted into arterial environments, Eph-B4 is found in both endothelial cells and smooth muscle cells, although Eph-B4 is preferentially distributed in endothelial cells (93). In cell culture, female-derived smooth muscle cells show more hypertrophic changes, whereas male-derived smooth muscle cells show more hyperplastic changes; additionally, female-derived cells were more adhesive, suggesting slower proliferation (114). In female rats, increased ER in smooth muscle cells was associated with reduced arterial contraction (115). Mineralocorticoid receptors in smooth muscle cells mediate later onset of aortic stiffening and vascular fibrosis in female mice compared with male mice (116). These studies suggest that sex differences in smooth muscle cell function may also be a mechanism of the sex differences observed during AVF maturation. However, the failed PREVENT trials 


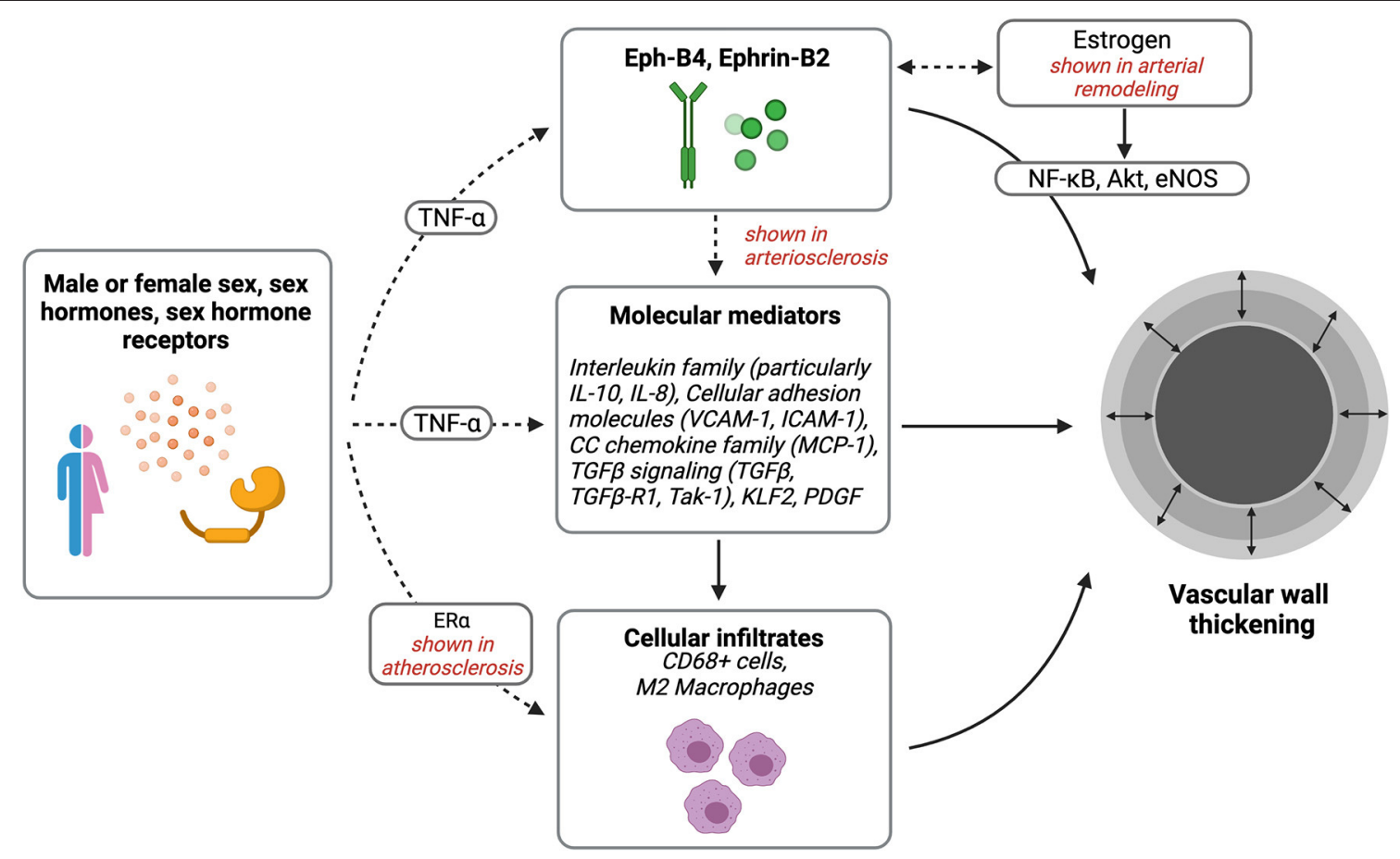

FIGURE 2 | Sex differences in vascular wall thickening. Potential pathways of interest in vessel wall thickening that may be affected by sex, sex hormones, and sex hormone receptors. Created with BioRender.com.

suggest that inhibition of smooth muscle cell proliferation during vein graft adaptation is unlikely to be a clinically successful strategy, and thus inhibition of smooth muscle cell function during AVF maturation would require another approach to optimize venous remodeling $(117,118)$.

\section{CONCLUSION}

AVF maturation and utilization remains poor, particularly in women. There is growing understanding of the inflammatory mechanisms that drive successful AVF maturation and may differ between men and women. Successful AVF creation depends on venous dilation and wall thickening, both of which involve inflammatory mechanisms. Outward remodeling is dependent on CD4+ T cells, and venous hyperplasia is dependent on distinct subsets of macrophages. In arterial aneurysms and atherosclerosis, where sex differences have long been recognized, there is a larger body of evidence supporting sex differences in inflammatory vessel remodeling. Mechanisms of arterial

\section{REFERENCES}

1. Iorga A, Cunningham CM, Moazeni S, Ruffenach G, Umar S, Eghbali M. The protective role of estrogen and estrogen receptors in cardiovascular disease and the controversial use of estrogen therapy. Biol Sex Differ. (2017) 8:33. doi: 10.1186/s13293-0170152-8 remodeling may help guide understanding of venous remodeling and may lead to improved clinical outcomes for women needing AVF.

\section{AUTHOR CONTRIBUTIONS}

SC and AD contributed to the conception and design of the study. SC, GW, JL, and AD performed the literature search, analyzed the data, synthesized the literature, and were responsible for writing the manuscript. DJ-W and AD provided critical expertise and expert revision. All authors contributed to manuscript revision, read, and approved the submitted version.

\section{FUNDING}

This work was supported by US National Institute of Health (NIH) grant R01-HL144476 (to AD) as well as with the resources and the use of facilities at the VA Connecticut Healthcare System, West Haven, CT. 
4. Lee T. Fistula first initiative: historical impact on vascular access practice patterns and influence on future vascular access care. Cardiovasc Eng Technol. (2017) 8:244-54. doi: 10.1007/s13239-017-0319-9

5. Gorecka J, Fereydooni A, Gonzalez L, Lee S, Liu S, Ono S, et al. Molecular targets for improving arteriovenous fistula maturation and patency. Vasc Investig Ther. (2019) 2:33-41. doi: 10.4103/vit.vit_9_19

6. El Khoury R, Russeau AP, Patel N, Dabbous F, Kechker I, Lipatov S, et al. Reliability of preoperative venous mapping ultrasonography in predicting for autogenous arteriovenous fistula maturation. J Vasc Surg. (2021) 73:178793. doi: 10.1016/j.jvs.2020.09.035

7. Oprea A, Molnar A, Vlăduţiu D, Scridon T, Trifan C, Săcui D, et al. Correlation between preoperative vein and artery diameters and arteriovenous fistula outcome in patients with end-stage renal disease. Med Pharm Reports. (2018) 91:399-407. doi: 10.15386/cjmed-1080

8. Lauvao LS, Ihnat DM, Goshima KR, Chavez LA, Gruessner AC, Mills JL. Vein diameter is the major predictor of fistula maturation. J Vasc Surg. (2009) 49:1499-504. doi: 10.1016/j.jvs.2009.02.018

9. Miller CD, Robbin ML, Allon M. Gender differences in outcomes of arteriovenous fistulas in hemodialysis patients. Kidney Int. (2003) 63:34652. doi: 10.1046/j.1523-1755.2003.00740.x

10. Lee T, Qian J, Thamer M, Allon M. Gender disparities in vascular access surgical outcomes in elderly hemodialysis patients. Am J Nephrol. (2019) 49:11-9. doi: 10.1159/000495261

11. Dunn J, Herscu G, Woo K. Factors influencing maturation time of native arteriovenous fistulas. Ann Vasc Surg. (2015) 29:704-7. doi: 10.1016/j.avsg.2014.11.026

12. Lu DY, Chen EY, Wong DJ, Yamamoto K, Protack CD, Williams WT, et al. Vein graft adaptation and fistula maturation in the arterial environment. $J$ Surg Res. (2014) 188:162-73. doi: 10.1016/j.jss.2014.01.042

13. de Vries MR, Quax PHA. Inflammation in vein graft disease. Front Cardiovasc Med. (2018) 5:3. doi: 10.3389/fcvm.2018.00003

14. Hiramoto JS, Owens CD, Kim JM, Boscardin J, Belkin M, Creager MA, et al. Sex-based differences in the inflammatory profile of peripheral artery disease and the association with primary patency of lower extremity vein bypass grafts. J Vasc Surg. (2012) 56:387-95. doi: 10.1016/j.jvs.2012.01.059

15. Nguyen LL, Hevelone N, Rogers SO, Bandyk DF, Clowes AW, Moneta GL, et al. Disparity in outcomes of surgical revascularization for limb salvage: race and gender are synergistic determinants of vein graft failure and limb loss. Circulation. (2009) 119:123-30. doi: 10.1161/CIRCULATIONAHA.108.810341

16. Protack CD, Foster TR, Hashimoto T, Yamamoto K, Lee MY, Kraehling JR, et al. Eph-B4 regulates adaptive venous remodeling to improve arteriovenous fistula patency. Sci Rep. (2017) 7:15386. doi: 10.1038/s41598-017-13071-2

17. Hall MR, Yamamoto K, Protack CD, Tsuneki M, Kuwahara G, Assi R, et al. Temporal regulation of venous extracellular matrix components during arteriovenous fistula maturation. J Vasc Access. (2015) 16:93106. doi: 10.5301/jva.5000290

18. Kania A, Klein R. Mechanisms of ephrin-Eph signalling in development, physiology and disease. Nat Rev Mol Cell Biol. (2016) 17:240-56. doi: 10.1038/nrm.2015.16

19. Kudo FA, Muto A, Maloney SP, Pimiento JM, Bergaya S, Fitzgerald TN, et al. Venous identity is lost but arterial identity is not gained during vein graft adaptation. Arterioscler Thromb Vasc Biol. (2007) 27:156271. doi: 10.1161/ATVBAHA.107.143032

20. Coulthard MG, Morgan M, Woodruff TM, Arumugam TV, Taylor SM, Carpenter TC, et al. Eph/ephrin signaling in injury and inflammation. Am J Pathol. (2012) 181:1493-503. doi: 10.1016/j.ajpath.2012.06.043

21. Braun J, Hoffmann SC, Feldner A, Ludwig T, Henning R, Hecker $M$, et al. Endothelial cell EphrinB2-dependent activation of monocytes in arteriosclerosis. Arterioscler Thromb Vasc Biol. (2011) 31:297-305. doi: 10.1161/ATVBAHA.110.217646

22. Wang M, Collins MJ, Foster TR, Bai H, Hashimoto T, Santana JM, et al. EphB4 mediates vein graft adaptation by regulation of endothelial nitric oxide synthase. J Vasc Surg. (2017) 65:179-89. doi: 10.1016/j.jvs.2015.11.041

23. Pike D, Shiu YT, Cho YF, Le $H$, Somarathna $M$, Isayeva $T$, et al. The effect of endothelial nitric oxide synthase on the hemodynamics and wall mechanics in murine arteriovenous fistulas. Sci Rep. (2019) 9:4299. doi: 10.1038/s41598-019-40683-7
24. Guo X, Razandi M, Pedram A, Kassab G, Levin ER. Estrogen induces vascular wall dilation: mediation through kinase signaling to nitric oxide and estrogen receptors $\alpha$ and $\beta$. J Biol Chem. (2005) 280:1970419710. doi: 10.1074/jbc.M501244200

25. Cattaneo MG, Vanetti C, Decimo I, Di Chio M, Martano G, Garrone G, et al. Sex-specific eNOS activity and function in human endothelial cells. Sci Rep. (2017) 7:9612. doi: 10.1038/s41598-017-10139-x

26. Majmudar NG, Robson SC, Ford GA. Effects of the menopause, gender, and estrogen replacement therapy on vascular nitric oxide activity. J Clin Endocrinol Metab. (2000) 85:1577-83. doi: 10.1210/jcem.85.4.6530

27. Colditz GA, Willett WC, Stampfer MJ, Rosner B, Speizer FE, Hennekens CH. Menopause and the risk of coronary heart disease in women. $N$ Engl J Med. (1987) 316:1105-10. doi: 10.1056/NEJM198704303161801

28. Guetta V, Quyyumi AA, Prasad A, Panza JA, Waclawiw M, Cannon RO. The role of nitric oxide in coronary vascular effects of estrogen in postmenopausal women. Circulation. (1997) 96:2795-801. doi: 10.1161/01.CIR.96.9.2795

29. Goumans MJ, Liu Z, Ten Dijke P. TGF- $\beta$ signaling in vascular biology and dysfunction. Cell Res. (2009) 19:116-27. doi: 10.1038/cr.2008.326

30. $\mathrm{Hu} \mathrm{H}, \mathrm{Hu} \mathrm{H}$, Lee SR, Lee SR, Bai $\mathrm{H}$, Bai $\mathrm{H}$, et al. TGF $\beta$ (transforming growth factor-beta)-activated kinase 1 regulates arteriovenous fistula maturation. Arterioscler Thromb Vasc Biol. (2020) 40:E203-13. doi: 10.1161/ATVBAHA.119.313848

31. Chen PY, Qin L, Li G, Wang Z, Dahlman JE, MalagonLopez J, et al. Endothelial TGF- $\beta$ signalling drives vascular inflammation and atherosclerosis. Nat Metab. (2019) 1:91226. doi: 10.1038/s42255-019-0102-3

32. Lee T, Roy-Chaudhury P. Advances and new frontiers in the pathophysiology of venous neointimal hyperplasia and dialysis access stenosis. Adv Chronic Kidney Dis. (2009) 16:329-38. doi: 10.1053/j.ackd.2009.06.009

33. Heine GH, Ulrich C, Sester U, Sester M, Köhler H, Girndt M. Transforming growth factor $\beta 1$ genotype polymorphisms determine AV fistula patency in hemodialysis patients. Kidney Int. (2003) 64:11017. doi: 10.1046/j.1523-1755.2003.00176.x

34. Shah TA, Rogers MB. Unanswered questions regarding sex and BMP/TGF- $\beta$ signaling. J Dev Biol. (2018) 6:14. doi: 10.3390/JDB6020014

35. Dela Justina V, Giachini FR, Sullivan JC, Webb RC. Toll-Like receptors contribute to sex differences in blood pressure regulation. J Cardiovasc Pharmacol. (2020) 76:255-66. doi: 10.1097/FJC.0000000000000869

36. Kudze T, Ono S, Fereydooni A, Gonzalez L, Isaji T, Hu H, et al. Altered hemodynamics during arteriovenous fistula remodeling leads to reduced fistula patency in female mice. JVS Vasc Sci. (2020) 1:4256. doi: 10.1016/j.jvssci.2020.03.001

37. Cai C, Kilari S, Singh AK, Zhao C, Simeon ML, Misra A, et al. Differences in transforming growth factor- $\beta 1 / \mathrm{BMP} 7$ signaling and venous fibrosis contribute to female sex differences in arteriovenous fistulas. J Am Heart Assoc. (2020) 9:e017420. doi: 10.1161/JAHA.120.017420

38. Wu XF, Zhang J, Paskauskas S, Xin SJ, Duan ZQ. The role of estrogen in the formation of experimental abdominal aortic aneurysm. Am J Surg. (2009) 197:49-54. doi: 10.1016/j.amjsurg.2007.11.022

39. Villard C, Swedenborg J, Eriksson P, Hultgren R. Reproductive history in women with abdominal aortic aneurysms. J Vasc Surg. (2011) 54:3415.e2. doi: 10.1016/j.jvs.2010.12.069

40. Cho BS, Roelofs KJ, Ford JW, Henke PK, Upchurch GR. Decreased collagen and increased matrix metalloproteinase-13 in experimental abdominal aortic aneurysms in males compared with females. Surgery. (2010) 147:25867. doi: 10.1016/j.surg.2009.06.047

41. Sinha I, Cho BS, Roelofs KJ, Stanley JC, Henke PK, Upchurch GR. Female gender attenuates cytokine and chemokine expression and leukocyte recruitment in experimental rodent abdominal aortic aneurysms. Ann N Y Acad Sci. (2006) 1085:367-79. doi: 10.1196/annals.13 83.027

42. Dimusto PD, Lu G, Ghosh A, Roelofs KJ, Sadiq O, McEvoy B, et al. Increased JNK in males compared with females in a rodent model of abdominal aortic aneurysm. J Surg Res. (2012) 176:687-95. doi: 10.1016/j.jss.2011.11.1024

43. Sangiorgi G, Roversi S, Biondi Zoccai G, Modena MG, Servadei F, Ippoliti A, et al. Sex-related differences in carotid plaque features and inflammation. $J$ Vasc Surg. (2013) 57:338-44. doi: 10.1016/j.jvs.2012.07.052 
44. Walpola PL, Gotlieb AI, Cybulsky MI, Langille BL. Expression of ICAM-1 and VCAM-1 and monocyte adherence in arteries exposed to altered shear stress. Arterioscler Thromb Vasc Biol. (1995) 15:210. doi: 10.1161/01.ATV.15.1.2

45. Intengan HD, Schiffrin EL. Vascular remodeling in hypertension: roles of apoptosis, inflammation, and fibrosis. Hypertension. (2001) 38:5817. doi: 10.1161/hy09t1.096249

46. Cunningham KS, Gotlieb AI. The role of shear stress in the pathogenesis of atherosclerosis. Lab Investig. (2005) 85:9-23. doi: 10.1038/labinvest.3700215

47. Yamada K, Hayashi T, Kuzuya M, Naito M, Asai K, Iguchi A. Physiological concentration of 17 beta-estradiol inhibits chemotaxis of human monocytes in response to monocyte chemotactic protein 1. Artery. (1996) 22:24-35.

48. Simoncini T, Maffei S, Basta G, Barsacchi G, Genazzani AR, Liao JK, et al. Estrogens and glucocorticoids inhibit endothelial vascular cell adhesion molecule-1 expression by different transcriptional mechanisms. Circ Res. (2000) 87:19-25. doi: 10.1161/01.RES.87.1.19

49. Chakrabarti S, Davidge ST. Estradiol modulates tumor necrosis factorinduced endothelial inflammation: role of tumor necrosis factor receptor 2.J Vasc Res. (2013) 50:21-34. doi: 10.1159/000342736

50. Hou X, Pei F. Estradiol inhibits cytokine-induced expression of VCAM-1 and ICAM-1 in cultured human endothelial cells via AMPK/PPARalpha activation. Cell Biochem Biophys. (2015) 72:709-17. doi: 10.1007/s12013-015-0522-y

51. Annibalini G, Agostini D, Calcabrini C, Martinelli C, Colombo E, Guescini $\mathrm{M}$, et al. Effects of sex hormones on inflammatory response in male and female vascular endothelial cells. J Endocrinol Invest. (2014) 37:8619. doi: 10.1007/s40618-014-0118-1

52. Marcus RJ, Marcus DA, Sureshkumar KK, Hussain SM, McGill RL. Gender differences in vascular access in hemodialysis patients in the United States: developing strategies for improving access outcome. Gend Med. (2007) 4:193-204. doi: 10.1016/S1550-8579(07)80040-4

53. Matsubara Y, Kiwan G, Fereydooni A, Langford J, Dardik A. Distinct subsets of $\mathrm{T}$ cells and macrophages impact venous remodeling during arteriovenous fistula maturation. JVS Vasc Sci. (2020) 1:207-18. doi: 10.1016/j.jvssci.2020.07.005

54. Duque JC, Martinez L, Mesa A, Wei Y, Tabbara M, Salman LH, et al. CD4+ lymphocytes improve venous blood flow in experimental arteriovenous fistulae. Surgery. (2015) 158:529-36. doi: 10.1016/j.surg.2015.02.018

55. Klein SL, Flanagan KL. Sex differences in immune responses. Nat Rev Immunol. (2016) 16:626-38. doi: 10.1038/nri.2016.90

56. Salem ML. Estrogen, a double-edged sword: modulation of TH1- and TH2-mediated inflammations by differential regulation of TH1/TH2 cytokine production. Curr Drug Targets Inflamm Allergy. (2004) 3:97104. doi: $10.2174 / 1568010043483944$

57. Girón-González JA, Moral FJ, Elvira J, García-Gil D, Guerrero F, Gavilán I, et al. Consistent production of a higher $\mathrm{T}(\mathrm{H}) 1: \mathrm{T}(\mathrm{H}) 2$ cytokine ratio by stimulated T cells in men compared with women. Eur J Endocrinol. (2000) 143:31-6. doi: 10.1530/eje.0.1430031

58. Wang $\mathrm{X}$, Khalil RA. Matrix metalloproteinases, vascular remodeling, and vascular disease. Adv Pharmacol. 81:241330. doi: 10.1016/bs.apha.2017.08.002

59. Palombo D, Maione M, Cifiello BI, Udini M, Maggio D, Lupo D. Matrix metalloproteinases. Their role in degenerative chronic diseases of abdominal aorta. J Cardiovasc Surg. (1999) 40:257-60.

60. Longo GM, Xiong W, Greiner TC, Zhao Y, Fiotti N, Baxter BT. Matrix metalloproteinases 2 and 9 work in concert to produce aortic aneurysms. $J$ Clin Invest. (2002) 110:625-32. doi: 10.1172/jci15334

61. Lee ES, Shen Q, Pitts RL, Guo M, Wu MH, Sun SC, et al. Serum metalloproteinases MMP-2, MMP-9, and metalloproteinase tissue inhibitors in patients are associated with arteriovenous fistula maturation. J Vasc Surg. (2011) 54:454-60. doi: 10.1016/j.jvs.2011.02.056

62. Papoutsis K, Kapelouzou A, Georgiopoulos G, Kontogiannis C, Kourek C, Mylonas KS, et al. Tissue-specific relaxin-2 is differentially associated with the presence/size of an arterial aneurysm and the severity of atherosclerotic disease in humans. Acta Pharmacol Sin. (2020) 41:74552. doi: 10.1038/s41401-019-0350-5

63. Jeyabalan A, Novak J, Doty KD, Matthews J, Fisher MC, Kerchner LJ, et al. Vascular matrix metalloproteinase- 9 mediates the inhibition of myogenic reactivity in small arteries isolated from rats after short-term administration of relaxin. Endocrinology. (2007) 148:189-97. doi: 10.1210/en.2006-0989

64. Debrah DO, Conrad KP, Danielson LA, Shroff SG. Effects of relaxin on systemic arterial hemodynamics and mechanical properties in conscious rats: sex dependency and dose response. J Appl Physiol. (2005) 98:101320. doi: 10.1152/japplphysiol.01083.2004

65. Conrad KP, Debrah DO, Novak J, Danielson LA, Shroff SG. Relaxin modifies systemic arterial resistance and compliance in conscious, nonpregnant rats. Endocrinology. (2004) 145:3289-96. doi: 10.1210/en.2003-1612

66. Sherwood OD. Relaxin's physiological roles and other diverse actions. Endocr Rev. (2004) 25:205-34. doi: 10.1210/er.2003-0013

67. Hashem G, Zhang Q, Hayami T, Chen J, Wang W, Kapila S. Relaxin and $\beta$-estradiol modulate targeted matrix degradation in specific synovial joint fibrocartilages: progesterone prevents matrix loss. Arthritis Res Ther. (2006) 8:R98. doi: 10.1186/ar1978

68. Winn RJ, Baker MD, Sherwood OD. Individual and combined effects of relaxin, estrogen, and progesterone in ovariectomized gilts. I. Effects on the growth, softening, and histological properties of the cervix. Endocrinology. (1994) 135:1241-9. doi: 10.1210/endo.135.3.8070369

69. Bezhaeva T, De Vries MR, Geelhoed WJ, Van Der Veer EP, Versteeg $S$, Van Alem CMA, et al. Relaxin receptor deficiency promotes vascular inflammation and impairs outward remodeling in arteriovenous fistulas. FASEB J. (2018) 32:6293-304. doi: 10.1096/fj.201800437R

70. Ailawadi G, Eliason JL, Roelofs KJ, Sinha I, Hannawa KK, Kaldjian EP, et al. Gender differences in experimental aortic aneurysm formation. Arterioscler Thromb Vasc Biol. (2004) 24:2116-22. doi: 10.1161/01.ATV.0000143386.26399.84

71. Wong CY, Rothuizen TC, De Vries MR, Rabelink TJ, Hamming JF, Van Zonneveld AJ, et al. Elastin is a key regulator of outward remodeling in arteriovenous fistulas. Eur J Vasc Endovasc Surg. (2015) 49:4806. doi: 10.1016/j.ejvs.2014.12.035

72. Bleyer AJ, Scavo VA, Wilson SE, Browne BJ, Ferris BL, Ozaki CK, et al. A randomized trial of vonapanitase (PATENCY-1) to promote radiocephalic fistula patency and use for hemodialysis. J Vasc Surg. (2019) 69:50715. doi: 10.1016/j.jvs.2018.04.068

73. Peden EK, Lucas JF, Browne BJ, Settle SM, Scavo VA, Bleyer AJ, et al. PATENCY-2 trial of vonapanitase to promote radiocephalic fistula use for hemodialysis and secondary patency. J Vasc Access. (2021) 1129729820985626. doi: 10.1177/1129729820985626. [Epub ahead of print].

74. Lederle FA, Johnson GR, Wilson SE, Chute EP, Hye RJ, Makaroun MS, et al. The aneurysm detection and management study screening program: validation cohort and final results. Arch Intern Med. (2000) 160:142530. doi: 10.1001/archinte.160.10.1425

75. Cheung K, Boodhwani M, Chan KL, Beauchesne L, Dick A, Coutinho T. Thoracic aortic aneurysm growth: role of sex and aneurysm etiology. J Am Heart Assoc. (2017) 6:e003792. doi: 10.1161/JAHA.116.003792

76. Solberg S, Singh K, Wilsgaard T, Jacobsen BK. Increased growth rate of abdominal aortic aneurysms in women. The tromsø study. Eur $J$ Vasc Endovasc Surg. (2005) 29:145-9. doi: 10.1016/j.ejvs.2004.11.015

77. Mofidi R, Goldie VJ, Kelman J, Dawson ARW, Murie JA, Chalmers RTA. Influence of sex on expansion rate of abdominal aortic aneurysms. Br J Surg. (2007) 94:310-4. doi: 10.1002/bjs.5573

78. Nienaber CA, Fattori R, Mehta RH, Richartz BM, Evangelista A, Petzsch M, et al. Gender-related differences in acute aortic dissection. Circulation. (2004) 109:3014-21. doi: 10.1161/01.CIR.0000130644.78677.2C

79. Spiliotopoulos K, Price MD, Amarasekara HS, Green SY, Zhang Q, Preventza $\mathrm{O}$, et al. Are outcomes of thoracoabdominal aortic aneurysm repair different in men versus women? A propensity-matched comparison. J Thorac Cardiovasc Surg. (2017) 154:1203-14.e6. doi: 10.1016/j.jtcvs.2017. 05.089

80. Dillavou ED, Muluk SC, Makaroun MS. A decade of change in abdominal aortic aneurysm repair in the United States: have we improved outcomes equally between men and women? J Vasc Surg. (2006) 43:2308. doi: 10.1016/j.jvs.2005.09.043

81. Boczar KE, Cheung K, Boodhwani M, Beauchesne L, Dennie C, Nagpal S, et al. Sex differences in thoracic aortic aneurysm growth: role of aortic stiffness. Hypertension. (2019) 73:1906. doi: 10.1161/HYPERTENSIONAHA.118.11851 
82. McPhee JT, Hill JS, Eslami MH. The impact of gender on presentation, therapy, and mortality of abdominal aortic aneurysm in the United States, 2001-2004. J Vasc Surg. (2007) 45:891-9. doi: 10.1016/j.jvs.2007.01.043

83. Natoli AK, Medley TL, Ahimastos AA, Drew BG, Thearle DJ, Dilley RJ, et al. Sex steroids modulate human aortic smooth muscle cell matrix protein deposition and matrix metalloproteinase expression. Hypertension. (2005) 46:1129-34. doi: 10.1161/01.HYP.0000187016.06549.96

84. Laser A, Ghosh A, Roelofs K, Sadiq O, McEvoy B, Dimusto P, et al. Increased estrogen receptor alpha in experimental aortic aneurysms in females compared with males. J Surg Res. (2014) 186:467-74. doi: 10.1016/j.jss.2013.07.050

85. Martin-McNulty B, Tham DM, Da Cunha V, Ho JJ, Wilson DW, Rutledge JC, et al. 17 $\beta$-estradiol attenuates development of angiotensin II-induced aortic abdominal aneurysm in apolipoprotein E-deficient mice. Arterioscler Thromb Vasc Biol. (2003) 23:1627-32. doi: 10.1161/01.ATV.0000085842.20866.6A

86. Huang CK, Luo J, Lai KP, Wang R, Pang H, Chang E, et al. Androgen receptor promotes abdominal aortic aneurysm development via modulating inflammatory interleukin- $1 \alpha$ and transforming growth factor- $\beta 1$ expression. Hypertension. (2015) 66:881-91. doi: 10.1161/HYPERTENSIONAHA.115.05654

87. Xing D, Feng W, Miller AP, Weathington NM, Chen YF, Novak L, et al. Estrogen modulates TNF-alpha-induced inflammatory responses in rat aortic smooth muscle cells through estrogen receptor-beta activation. Am J Physiol Heart Circ Physiol. (2007) 292:H2607-12. doi: 10.1152/ajpheart.01107.2006

88. Liang X, He M, Chen T, Wu Y, Tian Y, Zhao Y, et al. 17betaestradiol suppresses the macrophage foam cell formation associated with SOCS3. Horm Metab Res. (2013) 45:423-9. doi: 10.1055/s-0033-13 33751

89. Sagan A, Mikolajczyk TP, Mrowiecki W, MacRitchie N, Daly K, Meldrum $\mathrm{A}$, et al. $\mathrm{T}$ cells are dominant population in human abdominal aortic aneurysms and their infiltration in the perivascular tissue correlates with disease severity. Front Immunol. (2019) 10:1979. doi: 10.3389/fimmu.2019. 01979

90. Li H, Bai S, Ao Q, Wang X, Tian X, Li X, et al. Modulation of immune-inflammatory responses in abdominal aortic aneurysm: emerging molecular targets. J Immunol Res. (2018) 2018:7213760. doi: 10.1155/2018/72 13760

91. Schönbeck U, Sukhova GK, Gerdes N, Libby P. TH2 predominant immune responses prevail in human abdominal aortic aneurysm. Am J Pathol. (2002) 161:499-506. doi: 10.1016/S0002-9440(10)64206-X

92. Alexander MR, Moehle CW, Johnson JL, Yang Z, Lee JK, Jackson CL, et al. Genetic inactivation of IL-1 signaling enhances atherosclerotic plaque instability and reduces outward vessel remodeling in advanced atherosclerosis in mice. J Clin Invest. (2012) 122:70-9. doi: 10.1172/JCI 43713

93. Muto A, Yi T, Harrison KD, Dávalos A, Fancher TT, Ziegler KR, et al. Eph-B4 prevents venous adaptive remodeling in the adult arterial environment. J Exp Med. (2011) 208:561-75. doi: 10.1084/jem.201 01854

94. Wong DJ, Lu DY, Protack CD, Kuwahara G, Bai H, Sadaghianloo N, et al. Ephrin type-B receptor 4 activation reduces neointimal hyperplasia in human saphenous vein in vitro. J Vasc Surg. (2016) 63:795804. doi: 10.1016/j.jvs.2014.09.036

95. Model LS, Hall MR, Wong DJ, Muto A, Kondo Y, Ziegler KR, et al. Arterial shear stress reduces Eph-B4 expression in adult human veins. Yale J Biol Med. (2014) 87:359-71.

96. Berard X, Déglise S, Alonso F, Saucy F, Meda P, Bordenave L, et al. Role of hemodynamic forces in the ex vivo arterialization of human saphenous veins. J Vasc Surg. (2013) 57:1371-82. doi: 10.1016/j.jvs.2012. 09.041

97. Kang L, Grande JP, Farrugia G, Croatt AJ, Katusic ZS, Nath KA. Functioning of an arteriovenous fistula requires heme oxygenase. Am J Physiol Ren Physiol. (2013) 305:F545. doi: 10.1152/ajprenal.002 34.2013

98. Durante W, Lin CC. HOming in on arteriovenous fistula survival. Kidney Int. (2008) 74:9-11. doi: 10.1038/ki.2008.127
99. Sadaghianloo N, Contenti J, Declemy S, Ambrosetti D, Zdralevic M, Tannour-Louet $\mathrm{M}$, et al. Hypoxia and hypoxia-inducible factors promote the development of neointimal hyperplasia in arteriovenous fistula. J Physiol. (2021) 599:2299-321. doi: 10.1113/JP281218

100. Bohuslavová R, Kolár F, Kuthanová L, Neckár J, Tichopád A, Pavlinkova G. Gene expression profiling of sex differences in HIF1-dependent adaptive cardiac responses to chronic hypoxia. J Appl Physiol. (2010) 109:1195202. doi: 10.1152/japplphysiol.00366.2010

101. Toth B, Yokoyama Y, Kuebler JF, Schwacha MG, Rue LW, Bland KI, et al. Sex differences in hepatic heme oxygenase expression and activity following trauma and hemorrhagic shock. Arch Surg. (2003) 138:137582. doi: 10.1001/archsurg.138.12.1375

102. Cai C, Zhao C, Kilari S, Sharma A, Singh AK, Simeon ML, et al. Effect of sex differences in treatment response to angioplasty in a murine arteriovenous fistula model. Am J Physiol Renal Physiol. (2020) 318:F56575. doi: 10.1152/ajprenal.00474.2019

103. Kuwahara G, Hashimoto T, Tsuneki M, Yamamoto K, Assi R, Foster $\mathrm{TR}$, et al. CD44 promotes inflammation and extracellular matrix production during arteriovenous fistula maturation. Arterioscler Thromb Vasc Biol. (2017) 37:1147-56. doi: 10.1161/ATVBAHA.117. 309385

104. Guo X, Fereydooni A, Isaji T, Gorecka J, Liu S, Hu H, et al. Inhibition of the Akt1-mTORC1 axis alters venous remodeling to improve arteriovenous fistula patency. Sci Rep. (2019) 9:11046. doi: 10.1038/s41598-019-47 542-5

105. Misra S, Kilari S, Yang B, Sharma A, Wu C-C, Vazquez-Padron RI, et al. Anti human CX3CR1 VHH molecule attenuates venous neointimal hyperplasia of arteriovenous fistula in mouse model. J Am Soc Nephrol. (2021). doi: 10.1681/asn.2020101458. [Epub ahead of print].

106. Wong C, Bezhaeva T, Rothuizen TC, Metselaar JM, De Vries MR, Verbeek FPR, et al. Liposomal prednisolone inhibits vascular inflammation and enhances venous outward remodeling in a murine arteriovenous fistula model. Sci Rep. (2016) 6:30439. doi: 10.1038/srep30439

107. Voorzaat BM, van der Bogt KEA, Bezhaeva T, van Schaik J, Eefting D, van der Putten K, et al. A randomized trial of liposomal prednisolone (LIPMAT) to enhance radiocephalic fistula maturation: a pilot study. Kidney Int Reports. (2020) 5:1327-32. doi: 10.1016/j.ekir.2020.05.030

108. Fairweather D. Sex differences in inflammation during atherosclerosis. Clin Med Insights Cardiol. (2014) 8:49-59. doi: 10.4137/CMC.S17068

109. Mathur P, Ostadal B, Romeo F, Mehta JL. Gender-related differences in atherosclerosis. Cardiovasc Drugs Ther. (2015) 29:319-27. doi: 10.1007/s10557-015-6596-3

110. Man JJ, Beckman JA, Jaffe IZ. Sex as a biological variable in atherosclerosis. Circ Res. (2020) 126:1297-319. doi: 10.1161/CIRCRESAHA.120. 315930

111. Ng MK, Quinn CM, McCrohon JA, Nakhla S, Jessup W, Handelsman DJ, et al. Androgens up-regulate atherosclerosis-related genes in macrophages from males but not females: molecular insights into gender differences in atherosclerosis. J Am Coll Cardiol. (2003) 42:1306-13. doi: 10.1016/j.jacc.2003.07.002

112. Zhao J, Jourd'heuil FL, Xue M, Conti D, Lopez-Soler RI, Ginnan $\mathrm{R}$, et al. Dual function for mature vascular smooth muscle cells during arteriovenous fistula remodeling. J Am Heart Assoc. (2017) 6:e004891. doi: 10.1161/JAHA.116.004891

113. Roy-Chaudhury P, Arend L, Zhang J, Krishnamoorthy M, Wang Y, Banerjee $\mathrm{R}$, et al. Neointimal hyperplasia in early arteriovenous fistula failure. Am J Kidney Dis. (2007) 50:782-90. doi: 10.1053/j.ajkd.2007.07.019

114. Bačáková L, Pellicciari C, Bottone MG, Lisá V, Mareš V. A sex-related difference in the hypertrophic versus hyperplastic response of vascular smooth muscle cells to repeated passaging in culture. Histol Histopathol. (2001) 16:675-84. doi: 10.14670/HH-16.675

115. Ma Y, Qiao X, Falone AE, Reslan OM, Sheppard SJ, Khalil RA. Gender-specific reduction in contraction is associated with increased estrogen receptor expression in single vascular smooth muscle cells of female rat. Cell Physiol Biochem. (2010) 26:457-70. doi: 10.1159/0003 20569

116. DuPont JJ, Kim SK, Kenney RM, Jaffe IZ. Sex differences in the time course and mechanisms of vascular and cardiac aging in mice: role of the smooth 
muscle cell mineralocorticoid receptor. Am J Physiol - Hear Circ Physiol. (2021) 320:H169-80. doi: 10.1152/AJPHEART.00262.2020

117. Conte MS, Bandyk DF, Clowes AW, Moneta GL, Seely L, Lorenz TJ, et al. Results of PREVENT III: a multicenter, randomized trial of edifoligide for the prevention of vein graft failure in lower extremity bypass surgery. J Vasc Surg. (2006) 43:742-51. doi: 10.1016/j.jvs.2005.12.058

118. Alexander JH, Hafley G, Harrington RA, Peterson ED, Ferguson TB, Lorenz TJ, et al. Efficacy and safety of edifoligide, an E2F transcription factor decoy, for prevention of vein graft failure following coronary artery bypass graft surgery: PREVENT IV: a randomized controlled trial. J Am Med Assoc. (2005) 294:2446-54. doi: 10.1001/jama.294.19.2446
Conflict of Interest: The authors declare that the research was conducted in the absence of any commercial or financial relationships that could be construed as a potential conflict of interest.

Copyright $\odot 2021$ Chan, Weininger, Langford, Jane-Wit and Dardik. This is an open-access article distributed under the terms of the Creative Commons Attribution License (CC BY). The use, distribution or reproduction in other forums is permitted, provided the original author(s) and the copyright owner(s) are credited and that the original publication in this journal is cited, in accordance with accepted academic practice. No use, distribution or reproduction is permitted which does not comply with these terms. 